\title{
Cytokine-induced killer cells promote antitumor immunity
}

Jingting Jiang ${ }^{1 *}$, Changping $\mathrm{Wu}^{1}$ and Binfeng $\mathrm{Lu}^{2^{*}}$

\begin{abstract}
The number of immune cells, especially dendritic cells and cytotoxic tumor infiltrating lymphocytes (TIL), particularly Th1 cells, CD8 T cells, and NK cells is associated with increased survival of cancer patients. Such antitumor cellular immune responses can be greatly enhanced by adoptive transfer of activated type 1 lymphocytes. Recently, adoptive cell therapy based on infusion of ex vivo expanded TILs has achieved substantial clinical success. Cytokine-induced killer (CIK) cells are a heterogeneous population of effector CD8 T cells with diverse TCR specificities, possessing non-MHC-restricted cytolytic activities against tumor cells. Preclinical studies of CIK cells in murine tumor models demonstrate significant antitumor effects against a number of hematopoietic and solid tumors. Clinical studies have confirmed benefit and safety of CIK cell-based therapy for patients with comparable malignancies. Enhancing the potency and specificity of CIK therapy via immunological and genetic engineering approaches and identifying robust biomarkers of response will significantly improve this therapy.
\end{abstract}

\section{Introduction}

The presence of cytotoxic tumor infiltrating lymphocytes (TIL) within tumor is associated with increased survival of cancer patients $[1,2]$. Both antitumor adaptive and innate cellular immunity are important for resistance of tumor growth and eventual elimination of cancer. Theoretically, antitumor cellular immune responses can be greatly enhanced by adoptive transfer of lymphocytes, a term encompassing a strategy in which autologous $\mathrm{T}$ or NK cells are acquired from a cancer patient and then activated and expanded ex vivo prior to reinfusion. Adoptive cell therapy of cancer, first demonstrated in mice more than 50 year ago [3], has gained momentum in recent years due to impressive clinical experiences with melanoma patients [4]. This approach is based on ex vivo expansion of large numbers of TILs and selection of tumor-specific $\mathrm{T}$ cell lines. The major effectors of TIL cells are phenotypically $\mathrm{CD}^{+}{ }^{+} \mathrm{CD} 8^{+} \mathrm{T}$ cells and their anti-tumor functions are $\mathrm{MHC}$ restricted [5]. In contrast to tumor antigen-specific immunotherapy, there is potential utility of non-antigen specific cell-based therapy. Many patients with cancer are

\footnotetext{
*Correspondence: jjtnew@163.com; Binfeng@pitt.edu

'Department of Tumor Biological treatment, the Third Affiliated Hospital of Soochow University, 185 Juqian Street, Changzhou 213003, China

${ }^{2}$ Department of Immunology, University of Pittsburgh School of Medicine, 200 Lothrop Street E1047, Pittsburgh, PA 15261, USA
}

ineligible for TIL-based therapy because their TILs do not expand sufficiently or because their tumors have lost expression of antigens or MHC molecules or have extremely low numbers of TILs. Cytokine-induced killer (CIK) cells are a heterogeneous population of effector CD8 T cells with diverse TCR specificities, possessing non-MHC-restricted cytolytic activities against tumor cells. Therefore, CIK cells can lyse tumor cells in a nonMHC-restricted manner and can serve as an alternative cellular immunotherapy. This review summarizes technical aspects of CIK, current clinical experiences and future clinical utility.

\section{The cellular characteristics of CIK}

CIK cells are generated by in vitro expansion of peripheral blood lymphocytes (PBL) using anti-CD3 antibodies and IL-2. Short-term culture of human PBLs with IL-2 allows for proliferation and development of effector NK and nonspecific T-cells, with lymphokine-activated killer (LAK) activity [6,7]. LAK activity enables lysis of fresh tumor targets in a non-MHC restricted manner in vitro and also exerts in vivo anti-tumor effects. Nonetheless, using LAK cells as a tumor immunotherapy has not achieved much success clinically and is hampered by both the limited expansion of LAK cells in vitro and low cytolytic activity in vivo [8-10]. The human clinical extrapolation from murine immunotherapy models 
suggests that as many as $2 \times 10^{11}$ human LAK cells may be necessary to allow adequate anti-tumor responses [11]. It is not practical to obtain such a large number of LAK cells for immunotherapy in humans. In addition, LAK-based therapy was limited by high toxicity due to the required in vivo infusion of IL-2. A solution for this problem was to induce more potent cytotoxic activities in harvested $\mathrm{T}$ cells. For this purpose, agonistic monoclonal antibodies (mAbs) against CD3 and IL-2 have been added to the PBMC culture. In such culture, more than 1000 fold expansion of cells can be achieved over 21-day in vitro culture. In addition, these cultured cells have potent cytolytic activity and can lyse tumor cells [11]. The lytic activity of these cells can be further increased by adding other cytokines such as IFN- $\gamma$ and IL-1 $\beta$ [11]. The original culture conditions defining CIK activity was modified by adding IFN- $\gamma 24 \mathrm{~h}$ before addition of anti-CD3 $\mathrm{mAb}$ and IL-2, and the term CIK cell was used to distinguish them from conventional IL-2 activated LAK cells [12]. With a substantial increase in cytotoxicity on a per cell basis and a higher proliferative response, CIK cells had a more than 70 fold increase in total cytolytic activity per culture when compared with standard IL2-stimulated LAK cell activity [12].

Among expanded CIK cells, the cells with the greatest cytotoxicity against tumor cell lines express both the T-cell marker CD3 and the NK cell marker CD56. $\mathrm{CD}^{+} \mathrm{CD}^{+} 6^{+}$cells are rare in uncultured PBLs [13], consistent with the phenotype of resting naïve and memory $\mathrm{T}$ cells. When PBLs are cultured under CIK conditions for 21 days, more than $90 \%$ of the cells expanded are $\mathrm{CD}^{+}$[14]. They are constituted by about $70 \% \mathrm{CD}^{+}$and $30 \% \mathrm{CD}^{+}$cells. The percentage of $\mathrm{CD}^{+} \mathrm{CD}^{2} 6^{+}$cells also greatly increases and reaches a plateau after approximately 21 day of culture to more than 20 to $30 \%$ of the CIK cells, consistent with the generation of effector $\mathrm{T}$ cells in these cultures. Most of the $\mathrm{CD}^{+}{ }^{+} \mathrm{CD} 56^{+}$cells co-express $\mathrm{CD} 2, \mathrm{TCR} \alpha \beta$, and $\mathrm{CD} 8$ but are negative for $\mathrm{CD} 4$, the helper $\mathrm{T}$ cell marker and CD16, an NK cell marker. The cytotoxicity mediated by $\mathrm{CD}^{+} \mathrm{CD}^{+} 6^{+}$cells does not depend on $\mathrm{MHC}$, similar to that mediated by NK cells. Interestingly, antitumor activity is restricted to the $\mathrm{CD}^{+} \mathrm{CD} 56^{+} \mathrm{CIK}$ and alloreactivity against HLA-mismatched PBMC is restricted to the $\mathrm{CD}^{+}{ }^{+} \mathrm{CD} 56^{-} \mathrm{CIK}$ [15]. These cells differ from NK cells because they do not mediate antibody-dependent cell-mediated cytotoxicity (ADCC). $\mathrm{CD}^{+} \mathrm{CD} 56^{+}$cells expanded under these culture conditions are derived from $\mathrm{CD}^{+}{ }^{+} \mathrm{CD} 56^{-\mathrm{T}}$ cells and not from $\mathrm{CD} 3^{-} \mathrm{CD} 56^{+} \mathrm{NK}$ cells [16]. Following culture, $\mathrm{CD}^{+} \mathrm{CD}^{+}$but not $\mathrm{CD}^{+}{ }^{+} \mathrm{CD} 4^{+} \mathrm{T}$ cells express high levels of CD56. This is consistent with the fact that effector CD8 $\mathrm{T}$ cells possess high levels of cytotoxic activity [16]. In addition CIK cells are CD45RA ${ }^{+}$, CCR7, CD62L weakly positive, CD11a ${ }^{+}$,
$\mathrm{CD} 27^{+}, \mathrm{CD} 28^{+}$, macrophage inflammatory protein $1 \mathrm{a}^{+}$, perforin $^{+}$, Fas ligand ${ }^{+}$, suggesting these are largely terminally differentiated memory $\mathrm{T}$ cells [16]. Furthermore, the V $\beta$ repertoire in CIK cells at the end of culture is of polyclonal pattern. Thus, the CIK culture condition generated a heterogeneous population of effector CD8 $\mathrm{T}$ cells with diverse TCR specificity but possess nonMHC-restricted cytolytic activities against tumor cells.

\section{Molecular triggers of CIK cytolytic activities}

CIK cells possess potent cytotoxic activities against a number of tumor cell lines or freshly isolated tumor samples, including acute myeloid leukemia, chronic myeloid leukemia and B lymphoma cells [16-19]. Besides hematopoietic cancer cells [20], CIK cells exert potent in vivo antitumor effects on human solid tumors including liver cancer [21], gastric cancer [22], lung cancer [23], glioma [24] and others. In contrast, CIK cells demonstrate little or no cytolytic activity against normal bone marrow or spleen cells in vitro, with substantial specificity for tumor cells $[24,25]$.

Although CIK cells are capable of undergoing degranulation upon stimulation with either agonistic anti-CD3 mAbs or susceptible target tumor cells, the molecules on malignant cells that stimulate cytolytic activities of CIK cells do not involve MHC-TCR interaction. Tumor cell-triggered cytotolytic activities in CIK can not be inhibited by neutralizing CD3 or HLA-class I mAbs. In addition, cyclosporin (CsA) and FK506 inhibit anti-CD3-mediated degranulation, but do not affect cytotoxicity of CIK cells against tumor target cells [26]. CIK cell binding to target cells and formation of cellular conjugates with tumor cells are required for CIKmediated cytotoxicity against tumor cell lines [27]. Cell surface adhesion molecule leukocyte function associated antigen-1 (LFA-1) is known to participate in effector/target recognition and stable conjugate formation. CIK cells express LFA-1 and the most susceptible tumor cells express LFA-1 ligands such as ICAM-1, -2 , and -3 . CIK-tumor cell conjugate formation and cytotoxicity against tumor cells are strongly inhibited by anti-LFA-1 mAb, suggesting that LFA-1 has a critical role in binding to target as well as in enabling the cytotoxicity mediated by CIK cells $[26,27]$. Besides adhesion molecules, CIK cells express activating NK receptors, including NKG2D, DNAX accessory molecule-1 (DNAM-1), and low levels of NKp30. The NKG2D ligands such as MIC A/B and ULBPs are highly expressed on tumor cells [28]. Cell signaling through NKG2D, DNAM-1, or NKp30 results in CIK cell activation leading to degranulation and cytotoxicity. Neutralization of DNAM-1, NKG2D, and NKp30 by antibodies confirms that these molecules are involved in the TCR-independent tumor cell recognition and killing by CIK cells $[26,27,29]$. 


\section{Preclinical studies}

The severe combined immunodeficiency (SCID) mouse model has been used for testing non-MHC-restricted antitumor effects with adoptive transfer of human CIK cells [12]. CIK cell infusion significantly prolongs survival of SCID mice injected with human lymphoma cells when compared with control animals injected with tumor cells alone or animals treated with LAK cells. Thus CIK cells seem to have superior in vivo antitumor activity in SCID mice, when compared with cells with LAK activity [16]. Using the SCID model, CIK cells have been shown to have in vivo antitumor effect against a number of hematopoietic and solid tumors [30].

Mouse CIK cells also possess anti-tumor cytolytic activities. When murine spleen cells are cultured under CIK culture conditions for 21 days, the majority of the cells are $\mathrm{TCR} \alpha \beta^{+} \mathrm{CD} 3^{+} \mathrm{CD} 8^{+} \mathrm{T}$ cells [31]. Interestingly, approximately $20 \%$ to $50 \%$ of the cells express the NK markers NK1.1 and DX5, consistent with the phenotype of effector CD8 T cells. Cytotoxicity is greatest among cells expressing either NK1.1 or DX5. Expanded CD8 ${ }^{+} \mathrm{T}$ cells produce high levels of $\mathrm{T}_{\mathrm{H}} 1$-type cytokines such as IFN- $\gamma$ and inflammatory cytokines such as tumor necrosis factor $\alpha$.

The availability of murine CIK cells allows testing their antitumor functions in immune-competent inbred mice. Thirty minutes following intravenous injection, CIK cells can be detected in the lungs, followed by distribution of the cells to other sites including the liver and spleen, within the next 16 hours. By 72 hours, significant numbers of transferred CIK cells are found in cells infiltrating tumor. CIK cells remain at the tumor site for more than 9 days. In addition, transferred mouse CIK cells demonstrate potent antitumor effect against both allogeneic and syngeneic transplanted tumor [32].

\section{Clinical studies}

CIK cells have been evaluated as an adoptive cell immunotherapy for cancer patients in a number of clinical trials (summarized in Table 1). Peripheral blood mononuclear cells (PBMC) were isolated by apheresis. T cells were then activated, expanded, and differentiated by anti-CD3 in the presence of cytokines including IFN- $\gamma$, IL- $1 \alpha$, and IL-2 for 14 to 21 days to generate CIK, which were subsequently infused into patients (Figure 1). In the first phase I clinical study, autologous CIK cells transduced with the interleukin-2 gene were infused in patients with metastatic renal cancer, colorectal cancer and lymphoma [33]. Transfected CIK cells could be detected for up to 2 weeks following infusion by analyzing expression of the IL-2 transgene. Six patients progressed, three patients were stable, and one patient with lymphoma developed a complete response. In three patients, WHO grade 2 fever was observed, and no major side-effect was observed despite the use of the IL-2 transgene in CIK cells.

CIK clinical studies were done on hematologic malignancies. A Phase I trial of autologous CIK cells for the treatment of patients with relapsed Hodgkin's disease and non-Hodgkin's lymphoma was carried out on nine patients with advanced Hodgkin's disease $(n=7)$ and non-Hodgkin's lymphoma $(\mathrm{n}=2)$, who had relapsed after an autologous transplantation. Two patients had partial responses, and another two patients had stabilization of disease. Toxicity was minimal [14]. In another study, 6 advanced lymphomas were enrolled. One patient had CR with a median follow-up of 33 months [38]. Significant antitumor activity was reported against hematologic malignancies after hematopoietic cell transplant. A phase I study of allogeneic CIK cells in six leukemia patients relapsing after allogeneic haematopoietic stem cell transplantation (HSCT) was done. Acute GVHD (grade I and II) was observed in four patients. One patient had stable disease, one had hematologic improvement and three achieved complete responses [35]. The feasibility of CIK in patients with relapsed hematologic malignancies after allogeneic HCT was explored in another study. Eighteen patients were given CIK cell infusions at escalating doses. Acute GVHD grade I-II was seen in 2 patients, and 1 patient had limited chronic GVHD. Five patients had longer remissions. The therapy was well tolerated and induced a low incidence of GVHD [40]. These phase I clinical studies have yielded encouraging results and demonstrated the safety of using CIK cells as immunotherapeutic approach.

We (JJ and CW) reported the effects of autologous CIK cells together with chemotherapy on patients with advanced gastric cancer (stage IV) [34]. Fifty-seven patients were nonrandomly divided into two groups: those receiving chemotherapy plus CIK biotherapy and those treated with chemotherapy alone. Following CIK cell infusion, serum levels of tumor markers were significantly decreased, and the short-term curative effect and the quality of life (QOL) were improved in the patients treated by chemotherapy plus CIK cells when compared with patients treated by chemotherapy alone. Moreover, the 2-year survival was prolonged in the group treated by chemotherapy plus CIK cells when compared to the group treated with chemotherapy alone. Our follow-up study with a larger cohort of 156 patients further confirmed the benefit of CIK therapy [39]. In another report, we evaluated the clinical efficacy of chemotherapy when applied in combination with CIK cell therapy compared to chemotherapy alone [36]. Fifty-nine advanced non-small cell lung cancer (NSCLC) patients were randomly divided into two groups, chemotherapy alone (group A) and chemotherapy plus CIK cell transfusion (group B). Autologous CIK cells were induced from the patients' 
Table 1 Published CIK cell clinical studies

\begin{tabular}{llcll}
\hline Year & Tumor type & No. of cases & Culture condition & Authors \\
\hline 1999 & Renal cell carcinoma Colorectal carcinoma Lymphoma & 10 & IFN- $\gamma$, anti-CD3, IL2 plus IL-2 transgene & Schmidt-Wolf IG et al. [33] \\
2005 & Lymphoma & 9 & IFN- $\gamma$, anti-CD3, and IL2 & Leemhuis T et al. [14] \\
2006 & Gastric carcinoma & 57 & IFN- $\gamma$, anti-CD3, IL2 and IL-1alpha & Jiang JT et al. [34] \\
2007 & Leukemia & 11 & IFN- $\gamma$, anti-CD3 and IL2 & Introna M et al. [35] \\
2008 & Non-small cell lung cancer & 59 & IFN- $\gamma$, anti-CD3, IL2 and IL-1alpha & Wu CP et al. [36] \\
2009 & Hepatocellular carcinoma & 127 & IFN- $\gamma$, anti-CD3, IL2 and IL-1lalpha & Hui D et al. [37] \\
2009 & Renal cell carcinoma and lymphoma & 6 & IFN- $\gamma$, anti-CD3, and IL2 & Olioso P et al. [38] \\
2010 & Gastric carcinoma & 156 & IFN- $\gamma$, anti-CD3, IL2, and IL-1alpha & Jiang JT et al. [39] \\
2011 & relapsed hematologic malignancies & 18 & IFN- $\gamma$, anti-CD3, and IL2 & Laport GG et al. [40] \\
2012 & Renal cell carcinoma & 74 & IFN- - , anti-CD3, IL2, IL-1 beta & Liu L et al. [41]
\end{tabular}

peripheral blood mononuclear cells (PBMC) in vitro. We found that the QOL was improved in the patients treated by chemotherapy plus CIK biotherapy when compared with the patients treated by chemotherapy alone. The overall response rate (ORR) was $43.3 \%$ and $44.8 \%$ in groups $\mathrm{A}$ and $\mathrm{B}$, respectively. The time to progression was 4.67 months in group A and 6.65 months in group B and the median survival time was 11.0 months in group $A$ and 15.0 months in group B. Compared to patients in group $\mathrm{A}$, the patients in group $\mathrm{B}$ had significantly longer progression-free survival (PFS) $(\mathrm{p}=0.042)$ and overall survival (OS) $(\mathrm{p}=\overline{0} .02 \overline{9})$. No severe side-effect was observe⿳亠丷厂 in the
CIK cell transfusion patients. These studies demonstrate that chemotherapy plus CIK cells has significant benefits for patients who suffer from advanced gastric cancer and lung cancer with no severe side-effects $[34,36,39]$.

Two studies reported positive outcome for CIK therapy for patients with hepatocellular carcinoma. A clinical trial of postoperative adjuvant CIK immunotherapy following radical resection of hepatocellular carcinoma was reported. 127 patients were divided into 3 groups. After radical resection of the tumor, immunotherapy with CIK cells was performed for 3 courses in 41 patients (CIK-I group) and 6 courses in 43 patients (CIK-II group). The

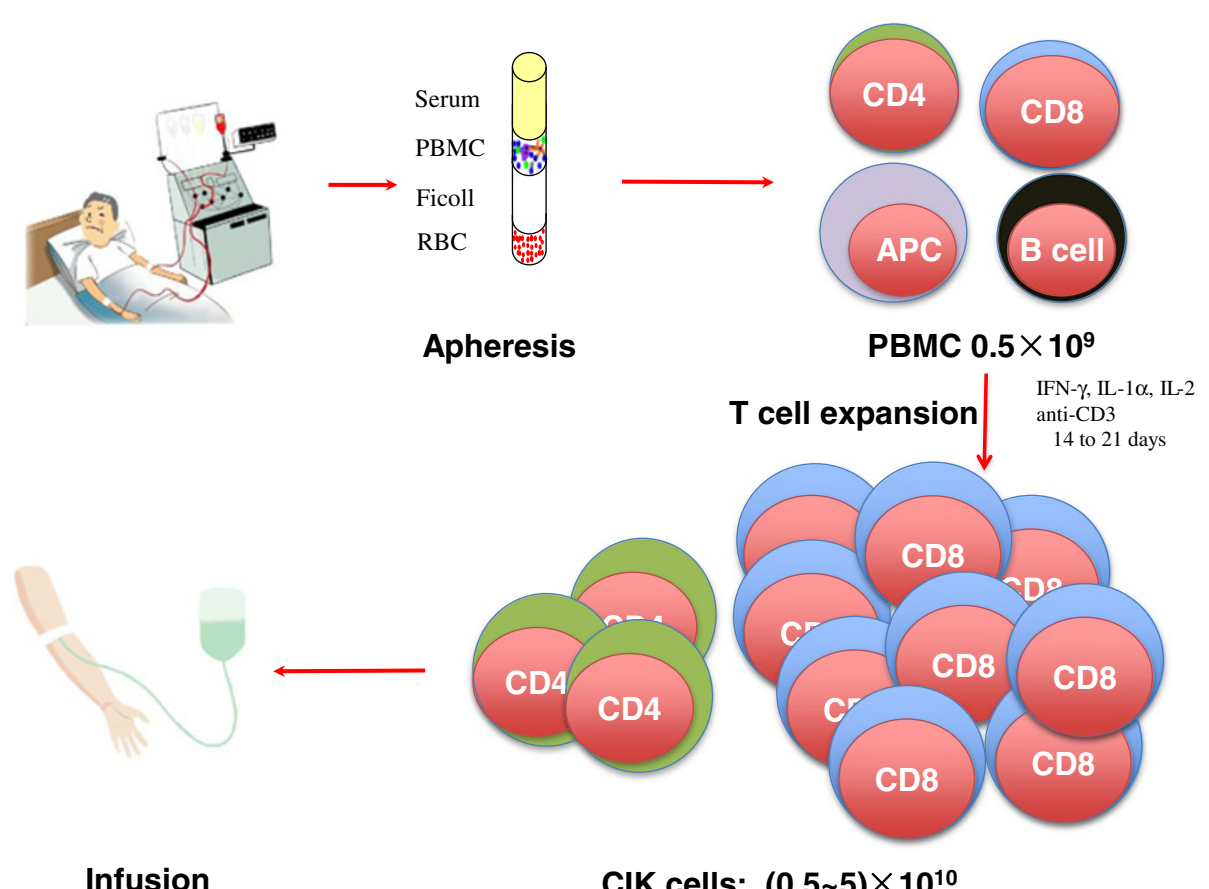

Figure 1 Procedure for CIK preparation and infusion. Peripheral blood mononuclear cells (PBMC) are isolated by apheresis. T cells are activated, expanded, and differentiated by anti-CD3 in the presence of cytokines including IFN- $\gamma$, IL-1a, and IL-2 for 14 to 21 days. These T cells, commonly called CIK, are then infused into patients. 
other 43 patients received no postoperative adjuvant therapy with CIK (the control group). The disease-free survival rates were significantly higher in the CIK-I group $(\mathrm{p}=0.001)$ and CIK-II group $(\mathrm{p}=0.004)$ than in the control group. In a separate study, adoptive CIK immunotherapy was also evaluated for reducing the recurrence of hepatocellular carcinoma (HCC) following minimally invasive therapy. $85 \mathrm{HCC}$ patients after transcatheter arterial chemoembolization and radiofrequency ablation therapy were randomized to the immunotherapy group and the no adjuvant therapy group. The 1-year and 18-month recurrence rates of the CIK group were $8.9 \%$ and $15.6 \%$, compared with $30.0 \%$ and $40.0 \%$ of the control group (both p values $<0.05$ ).

CIK has also been tried on renal cell carcinoma (RCC). The results of randomized study of autologous cytokine-induced killer cell immunotherapy in metastatic renal carcinoma have been reported recently [41]. 148 patients with metastatic clear cell RCC were randomized and assigned to two groups: i.e. autologous CIK cell immunotherapy (arm 1, n=74) and interleukin-2 treatment in combination with IFN- $\alpha-2 \mathrm{a}(\operatorname{arm} 2, \mathrm{n}=74)$. The 3 -year PFS in arm 1 was significant greater than that in arm 2 (18\% versus 12\%, p=0.031). And the 3 -year OS in arm 1 was also significantly greater than that in arm 2 (61\% versus 23\%, $\mathrm{p}<0.001$ ). The median PFS and OS in the CIK arm were significantly longer than those in the control arm (PFS, 12 vs. 8 months, $\mathrm{p}=0.024$; OS, 46 vs. 19 months, $\mathrm{p}<0.001)$. In another study, 5 metastatic kidney carcinoma patients were enrolled. One patient had CR and two patients had SD with a median follow-up of 33 months [38]. The studies suggested that CIK cell immunotherapy could improve the prognosis of metastatic clear cell RCC with minor side effect.

Recently, the international registry on CIK Cells (IRCC) has been established to collect data worldwide and set standard criteria to report results from clinical trials performed with CIK cells [42]. 11 clinical trials with CIK cells were identified. Of the 384 patients, where clinical response information was available, 24 patients showed a complete response, 27 patients showed a partial response, 40 patients showed a minor response. The total response rate (RR) was 91/384 reported patients, 161 patients had a stable disease, 129 patients had progressive disease. Side effects of CIK cell treatment were minor. Disease-free survival rates were significantly higher in patients treated with CIK cells than in a control group without the CIK treatment.

We have recently reviewed the results published in Chinese in a separate paper [43]. We collected results from 24 clinical trials. Among these trials, 936 patients were treated with CIK cells, including 525 men and 246 women. In five studies, CIK cells were co-cultured with dendritic cells (DCs). The total number of CIK cells used ranged from $6 \times 10^{6}$ to $1.5 \times 10^{10}$. Of the 563 patients, where a clinical response was reported, 40 had CR, 126 had PR, 125 had MR, 135 had SD, 58 had PD. The total response rate (RR) was $51.7 \%(291 / 563)$. The toxicities were minimal. These results demonstrate that CIK cell treatment is a promising and safe modality for treating solid tumor.

\section{Improving CIK therapy for epithelial cancer}

The total antitumor cytolytic activity within cell culture has been used as the sole marker for the success of CIK generation $[11,12]$. This is influenced by $\mathrm{T}$ cell proliferation as well as the development of effector function. Most of the studies use T cells cultured for 14 to 21 days. Cytokines such as IFN- $\gamma$, IL-1, IL-2, IL-7, IL-15, and IL-12 have been evaluated for their ability to promote the CIK generation [12,44-48]. According to the standard CIK culture condition, IFN- $\gamma$ is added at the beginning of the culture and $24 \mathrm{~h}$ before the addition of anti-CD3 $\mathrm{mAb}$ and IL-2 [12]. This is likely due to its role in promoting IL-12 production by antigen presenting cells as well as its ability to promote generation of autophagy and antigen cross-presentation. In contrast, IL-2, IL-7, IL-15 and IL-12 can directly promote $\mathrm{T}$ cell proliferation/survival and development of cytolytic effector functions. Other proproliferative cytokines such as IL-21 and IL-23 need to be tested separately or in combination with the cytokines currently used in the CIK culture to examine whether they can further promote CD8 $\mathrm{T}$ cell proliferation. In addition to IL-1, other members of the IL-1 protein family such as IL-18 and IL-33 promote CD8 and Th1 effector functions $[49,50]$. These cytokines should be tested in CIK cultures to determine whether they can promote cytolytic activities of CIK cells. Furthermore, co-stimulatory molecules such as CD28 and 4-1BB may also promote the efficient production of CIK cells.

The existence of anti-tumor-specific T-cells in cancer patients has been well documented. A potential mechanism of action for CIK is enhancement of a recall antitumor response by $\mathrm{CD}_{4} 5 \mathrm{RO}^{+}$memory T-cells. It is possible that spontaneous tumor-specific $\mathrm{T}$ cells are expanded with other non-specific T cells during CIK culture. Study on CMV-specific $\mathrm{T}$ cells showed that the percentage of CMV tetramer ${ }^{+} \mathrm{T}$ cells did not significantly change from the beginning to the end of the culture, suggesting that CMV tetramer ${ }^{+} \mathrm{T}$ cells expanded with similar efficiency with the total CD8 T cells [27]. Thus, tumor-specific components of CIK cells might be responsible for the clinical benefit observed in some cancer patients [51].

Besides spontaneous antitumor cellular responses, some chemotherapy regimens can induce tumor-specific $\mathrm{T}$ cells in cancer patients by inducing the immunogenic death of tumor cells or by engaging immune effector mechanisms [52]. Consistent with this idea, our previous studies 
showed that CIK following chemotherapy significantly prolonged the survival of patients with advanced gastric cancer $[34,36,39]$. The underlying mechanism needs to be further studied in order to improve the combined therapy. Future studies should focus on determining which chemotherapy regimen has the greatest synergy with $\mathrm{CIK}$ and the associated mechanisms. A recent study showed that autophagy is required for immunogenicity of tumor under chemotherapy. This is due to the fact that suppression of autophagy inhibits the release of adenosine triphosphate (ATP), a key danger signal, from dying tumor cells [53,54]. Thus, thermotherapy that enhances autophagy in cancer cells might synergize with CIK therapy.

CIK cells can be rendered tumor antigen-specific by transduction with the retrovirus vectors encoding either high affinity $\mathrm{T}$ cell receptors (TCR) or chimeric antibody-T cell receptors (CAR) which recognize tumor antigens [55]. Patients with melanoma have been treated with $\mathrm{T}$ cells engineered to express high affinity TCRs specific for melanoma antigens MART-1, gp100 and NY-ESO-1 [56-58]. Objective clinical responses have been reported, although some patients experienced autoimmune responses, suggesting TCRs need to be carefully selected $[56,57]$. CARs consist of the variable region of a tumor specific monoclonal antibody fused to an intracellular domains CD3 zeta and CD28. Autologous activated $\mathrm{T}$ cells genetically engineered to express the anti-CD19 CAR have been effective in treating patients with lymphoma and chronic lymphocytic leukemia (CLL) [59-62]. The side effect of this approach includes elimination of normal B cells in these patients. Besides the genetic engineering approach, tumor targeting can also be made specific using a bi-specific antibody with one part recognizing a surface tumor antigen and the other part binding to a $\mathrm{T}$ cell membrane protein [63-65]. The clinical efficacy of such approach remains to be evaluated.

It was originally reported that CIK cells could be ex vivo expanded up to 1000 fold with standardized conditions. However, it is a practical clinical problem that individual variability exists in expansion rates. This is likely due to immune suppression in cancer patients. Myeloid derived suppressor cells contaminated in the PBMC preparation or defective antigen presenting cells might inhibit $\mathrm{T}$ cell expansion [66]. In addition, $\mathrm{T}$ cells in cancer patients might be in a stage of anergy and exhaustion [67]. Many new approaches should be tested including using autologous dendritic cells (DC-CIK) or allo-antigen presenting cells [68].

Due to their abilities to migrate to tumor site, CIK cells can also be used to deliver bio-therapeutic agents to the tumor site. One study combined CIK cells with an oncolytic viral therapy and achieved directed delivery to, and regression of, tumors in mouse models [69]. The CIK cells retained their ability to traffic to and to infiltrate the tumor effectively before releasing the virus and the modified vaccinia virus remains inactive until the CIK cell encounters with the tumor. These results highlight the idea that CIK cells can be used as a vehicle for delivering biologic drugs directly to the tumor microenvironment. In addition, finding ways to limit induction of autophagy and resistance to immune-mediated effectors are also promising strategies to couple with adoptive transfer of CIK cells [70-72]. Trafficking of CIK cells is hard to investigate in cancer patients. One approach to further study the trafficking is to use various humanized mouse models [73]. In vivo trafficking can also be studied by tracking genetically engineered T cells upon infusion [74].

The survival of adoptively transferred CIK cells needs to be further studied in patients and humanized mouse models. CIK cells are composed of a mixture of effector and central memory $\mathrm{T}$ cells. Effector $\mathrm{T}$ cells, although possess potent immediate cytotoxic activities, produce a large amount of IFN- $\gamma$ and express high levels of NKG2D, are known to be prone to apoptosis. Central memory $\mathrm{T}$ cells and memory stem $\mathrm{T}$ cells, although require restimulation in vivo to gain effector functions, are more resistant to apoptosis than effector $\mathrm{T}$ cells [75-78]. Therefore, studying the in vivo survival of distinctive subsets of CIK cells and its relationship to clinical outcome should help improve this therapy.

So far there is no reliable biomarker for estimating clinical responses and predicting outcomes of CIK therapy. Among many changes in the blood, it has been shown that CD4/CD8 ratio and percentage of NK cells are significantly increased in patients infused with CIK [34,36]. Whether this or other markers correlate with clinical outcome is not known $[34,36]$. The frequency of tumor antigen-specific $\mathrm{T}$ cells should be studied in future clinical trials to examine whether it is associated with better patient outcome. In addition to blood marker, immunosuppressive molecules that are expressed in the tumor microenvironment, such as members of B7 family, should be further studied to determine whether they can serve as prognostic markers for the CIK therapy $[79,80]$.

\section{Conclusions}

Current clinical studies suggest that $\mathrm{CIK}$ is a promising and safe modality for treating malignancies. Multicenter clinical trials are warranted to further establish the validity of this therapeutic approach and optimize the CIK treatment protocol. This therapy should be further improved through increasing the specificity of CIK cells via immunological and genetic engineering approaches and identifying robust predictive biomarkers for patient stratification. In addition, we believe combining chemotherapy, radiotherapy or other immunotherapy approaches with CIK will further improve cancer therapy and prolong survival of cancer patients. 


\section{Competing interests}

The authors declare that they have no competing interests.

\section{Authors' contributions}

JJ: drafted the manuscript. CW: drafted parts of the manuscript. BL: drafted the manuscript. All authors read and approved the final manuscript.

\section{Acknowledgement}

Authors thank Drs Michael Lotze, Lisa Butterfield, and Stephen Thorne for critical reading of the manuscript. This research project was supported by the National Natural Science Foundation of China (NSFC) (81171653 and 30972703) and Natural Science Foundation of Jiangsu Province (BK2011246 and BK2011247), and Jiangsu Provincial Innovation Award BC2012093 by the Bureau of Science and Technology of Jiangsu Province. The project was supported by the National Institutes of Health through Grant Numbers UL1 RR024153, UL1TR000005 and R21CA167229.

Received: 12 December 2012 Accepted: 20 March 2013 Published: 28 March 2013

\section{References}

1. Fox BA, Schendel DJ, Butterfield LH, Aamdal S, Allison JP, Ascierto PA, Atkins MB, Bartunkova J, Bergmann L, Berinstein N, et al: Defining the critical hurdles in cancer immunotherapy. J Trans/ Med 2011, 9:214.

2. Fridman WH, Galon J, Pages F, Tartour E, Sautes-Fridman C, Kroemer G: Prognostic and predictive impact of intra- and peritumoral immune infiltrates. Cancer Res 2011, 71:5601-5605.

3. Mitchison NA: Studies on the immunological response to foreign tumor transplants in the mouse. I. The role of lymph node cells in conferring immunity by adoptive transfer. J Exp Med 1955, 102:157-177.

4. Rosenberg SA, Yang JC, Sherry RM, Kammula US, Hughes MS, Phan GQ, Citrin DE, Restifo NP, Robbins PF, Wunderlich JR, et al: Durable complete responses in heavily pretreated patients with metastatic melanoma using T-cell transfer immunotherapy. Clin Cancer Res 2011, 17:4550-4557.

5. Rosenberg SA, Spiess P, Lafreniere R: A new approach to the adoptive immunotherapy of cancer with tumor-infiltrating lymphocytes. Science 1986, 233:1318-1321

6. Yron I, Wood TA Jr, Spiess PJ, Rosenberg SA: In vitro growth of murine T cells. V. The isolation and growth of lymphoid cells infiltrating syngeneic solid tumors. J Immunol 1980, 125:238-245.

7. Lotze MT, Line BR, Mathisen DJ, Rosenberg SA: The in vivo distribution of autologous human and murine lymphoid cells grown in T cell growth factor (TCGF): implications for the adoptive immunotherapy of tumors. J Immunol 1980, 125:1487-1493.

8. Mule JJ, Shu S, Schwarz SL, Rosenberg SA: Adoptive immunotherapy of established pulmonary metastases with LAK cells and recombinant interleukin-2. Science 1984, 225:1487-1489.

9. Parkhurst MR, Riley JP, Dudley ME, Rosenberg SA: Adoptive transfer of autologous natural killer cells leads to high levels of circulating natural killer cells but does not mediate tumor regression. Clin Cancer Res 2011, 17:6287-6297.

10. Lotze MT, Grimm EA, Mazumder A, Strausser JL, Rosenberg SA: Lysis of fresh and cultured autologous tumor by human lymphocytes cultured in T-cell growth factor. Cancer Res 1981, 41:4420-4425.

11. Ochoa AC, Gromo G, Alter BJ, Sondel PM, Bach FH: Long-term growth of lymphokine-activated killer (LAK) cells: role of anti-CD3, beta-IL 1, interferon-gamma and -beta. J Immunol 1987, 138:2728-2733.

12. Schmidt-Wolf IG, Negrin RS, Kiem HP, Blume KG, Weissman IL: Use of a SCID mouse/human lymphoma model to evaluate cytokine-induced killer cells with potent antitumor cell activity. J Exp Med 1991, 174:139-149.

13. Schmidt-Wolf IG, Lefterova P, Mehta BA, Fernandez LP, Huhn D, Blume KG, Weissman IL, Negrin RS: Phenotypic characterization and identification of effector cells involved in tumor cell recognition of cytokine-induced killer cells. Exp Hematol 1993, 21:1673-1679.

14. Leemhuis T, Wells S, Scheffold C, Edinger M, Negrin RS: A phase I trial of autologous cytokine-induced killer cells for the treatment of relapsed Hodgkin disease and non-Hodgkin lymphoma. Biol Blood Marrow Transplant 2005, 11:181-187.
15. Sangiolo D, Martinuzzi E, Todorovic M, Vitaggio K, Vallario A, Jordaney N, Carnevale-Schianca F, Capaldi A, Geuna M, Casorzo L, et al: Alloreactivity and anti-tumor activity segregate within two distinct subsets of cytokine-induced killer (CIK) cells: implications for their infusion across major HLA barriers. Int Immunol 2008, 20:841-848.

16. Lu PH, Negrin RS: A novel population of expanded human CD3+CD56+ cells derived from $T$ cells with potent in vivo antitumor activity in mice with severe combined immunodeficiency. J Immunol 1994, 153:1687-1696.

17. Silva MR, Parreira A, Ascensao $\mathrm{J}$ : Natural killer cell numbers and activity in mobilized peripheral blood stem cell grafts: conditions for in vitro expansion. Exp Hematol 1995, 23:1676-1681

18. Hoyle C, Bangs CD, Chang P, Kamel O, Mehta B, Negrin RS: Expansion of Philadelphia chromosome-negative CD3(+)CD56(+) cytotoxic cells from chronic myeloid leukemia patients: in vitro and in vivo efficacy in severe combined immunodeficiency disease mice. Blood 1998, 92:3318-3327.

19. Linn YC, Lau LC, Hui KM: Generation of cytokine-induced killer cells from leukaemic samples with in vitro cytotoxicity against autologous and allogeneic leukaemic blasts. Br J Haematol 2002, 116:78-86.

20. Hongeng S, Petvises S, Worapongpaiboon S, Rerkamnuaychoke B, Pakakasama S, Jootar S: Generation of CD3+ CD56+ cytokine-induced killer cells and their in vitro cytotoxicity against pediatric cancer cells. Int J Hematol 2003, 77:175-179.

21. Wang FS, Liu MX, Zhang B, Shi M, Lei ZY, Sun WB, Du QY, Chen JM: Antitumor activities of human autologous cytokine-induced killer (CIK) cells against hepatocellular carcinoma cells in vitro and in vivo. World J Gastroenterol 2002, 8:464-468.

22. Sun S, Li XM, Li XD, Yang WS: Studies on inducing apoptosis effects and mechanism of CIK cells for MGC-803 gastric cancer cell lines. Cancer Biother Radiopharm 2005, 20:173-180.

23. Kim HM, Lim J, Park SK, Kang JS, Lee K, Lee CW, Lee KH, Yun MJ, Yang KH, Han $G$, et al: Antitumor activity of cytokine-induced killer cells against human lung cancer. Int Immunopharmacol 2007, 7:1802-1807.

24. Wang P, Yu JP, Gao SY, An XM, Ren XB, Wang XG, Li WL: Experimental study on the treatment of intracerebral glioma xenograft with human cytokine-induced killer cells. Cell Immunol 2008, 253:59-65.

25. Verneris MR, Ito M, Baker J, Arshi A, Negrin RS, Shizuru JA: Engineering hematopoietic grafts: purified allogeneic hematopoietic stem cells plus expanded CD8+ NK-T cells in the treatment of lymphoma. Biol Blood Marrow Transplant 2001, 7:532-542.

26. Mehta BA, Schmidt-Wolf IG, Weissman IL, Negrin RS: Two pathways of exocytosis of cytoplasmic granule contents and target cell killing by cytokine-induced CD3+ CD56+ killer cells. Blood 1995, 86:3493-3499.

27. Pievani A, Borleri G, Pende D, Moretta L, Rambaldi A, Golay J, Introna M: Dual-functional capability of CD3+CD56+ CIK cells, a T-cell subset that acquires NK function and retains TCR-mediated specific cytotoxicity. Blood 2011, 118:3301-3310.

28. Girardi M, Oppenheim DE, Steele CR, Lewis JM, Glusac E, Filler R, Hobby P, Sutton B, Tigelaar RE, Hayday AC: Regulation of cutaneous malignancy by gammadelta T cells. Science 2001, 294:605-609.

29. Karimi M, Cao TM, Baker JA, Verneris MR, Soares L, Negrin RS: Silencing human NKG2D, DAP10, and DAP12 reduces cytotoxicity of activated CD8+ T cells and NK cells. J Immunol 2005, 175:7819-7828.

30. Thanendrarajan S, Nowak M, Abken H, Schmidt-Wolf IG: Combining cytokine-induced killer cells with vaccination in cancer immunotherapy: more than one plus one? Leuk Res 2011, 35:1136-1142.

31. Baker J, Verneris MR, Ito M, Shizuru JA, Negrin RS: Expansion of cytolytic CD8(+) natural killer T cells with limited capacity for graft-versus-host disease induction due to interferon gamma production. Blood 2001, 97:2923-2931.

32. Edinger M, Cao YA, Verneris MR, Bachmann MH, Contag CH, Negrin RS Revealing lymphoma growth and the efficacy of immune cell therapies using in vivo bioluminescence imaging. Blood 2003, 101:640-648.

33. Schmidt-Wolf IG, Finke S, Trojaneck B, Denkena A, Lefterova P, Schwella N, Heuft HG, Prange G, Korte M, Takeya M, et al: Phase I clinical study applying autologous immunological effector cells transfected with the interleukin-2 gene in patients with metastatic renal cancer, colorectal cancer and lymphoma. Br J Cancer 1999, 81:1009-1016.

34. Jiang J, Xu N, Wu C, Deng H, Lu M, Li M, Xu B, Wu J, Wang R, Xu J, NilssonEhle $P$ : Treatment of advanced gastric cancer by chemotherapy combined with autologous cytokine-induced killer cells. Anticancer Res 2006, 26:2237-2242. 
35. Introna M, Borleri $G$, Conti $E$, Franceschetti M, Barbui AM, Broady R, Dander E, Gaipa G, D'Amico G, Biagi E, et al: Repeated infusions of donor-derived cytokine-induced killer cells in patients relapsing after allogeneic stem cell transplantation: a phase I study. Haematologica 2007, 92:952-959.

36. Wu C, Jiang J, Shi L, Xu N: Prospective study of chemotherapy in combination with cytokine-induced killer cells in patients suffering from advanced non-small cell lung cancer. Anticancer Res 2008, 28:3997-4002.

37. Hui D, Qiang L, Jian W, Ti Z, Da-Lu K: A randomized, controlled trial of postoperative adjuvant cytokine-induced killer cells immunotherapy after radical resection of hepatocellular carcinoma. Dig Liver Dis 2009, 41:36-41.

38. Olioso P, Giancola R, Di Riti M, Contento A, Accorsi P, lacone A: Immunotherapy with cytokine induced killer cells in solid and hematopoietic tumours: a pilot clinical trial. Hematol Oncol 2009, 27:130-139.

39. Jiang JT, Shen YP, Wu CP, Zhu YB, Wei WX, Chen L, Zheng X, Sun J, Lu BF, Zhang XG: Increasing the frequency of CIK cells adoptive immunotherapy may decrease risk of death in gastric cancer patients. World J Gastroenterol 2010, 16:6155-6162.

40. Laport GG, Sheehan K, Baker J, Armstrong R, Wong RM, Lowsky R, Johnston $\sqcup$, Shizuru JA, Miklos D, Arai S, et al: Adoptive immunotherapy with cytokine-induced killer cells for patients with relapsed hematologic malignancies after allogeneic hematopoietic cell transplantation. Biol Blood Marrow Transplant 2011, 17:1679-1687.

41. Liu L, Zhang W, Qi X, Li H, Yu J, Wei S, Hao X, Ren X: Randomized study of autologous cytokine-induced killer cell immunotherapy in metastatic renal carcinoma. Clin Cancer Res 2012, 18:1751-1759.

42. Hontscha C, Borck Y, Zhou H, Messmer D, Schmidt-Wolf IG: Clinical trials on CIK cells: first report of the international registry on CIK cells (IRCC). J Cancer Res Clin Oncol 2011, 137:305-310.

43. Li X, Xu B, Wu J: Review of Chinese clinical trial trials on CIK cell treatment for malignancies. Clin Trans/ Oncol 2012, 14:242-245.

44. Zoll B, Lefterova P, Ebert O, Huhn D, Von Ruecker A, Schmidt-Wolf IG: Modulation of cell surface markers on NK-like T lymphocytes by using IL-2, IL-7 or IL-12 in vitro stimulation. Cytokine 2000, 12:1385-1390.

45. Li Y, Schmidt-Wolf IG, Wu YF, Huang SL, Wei J, Fang J, Huang K, Zhou DH: Optimized protocols for generation of cord blood-derived cytokineinduced killer/natural killer cells. Anticancer Res 2010, 30:3493-3499.

46. Rettinger E, Kuci S, Naumann I, Becker P, Kreyenberg H, Anzaghe M, Willasch A, Koehl U, Bug G, Ruthardt M, et al: The cytotoxic potential of interleukin-15-stimulated cytokine-induced killer cells against leukemia cells. Cytotherapy 2011, 6:6.

47. Zoll B, Lefterova P, Csipai M, Finke S, Trojaneck B, Ebert O, Micka B, Roigk K Fehlinger M, Schmidt-Wolf GD, et al: Generation of cytokine-induced killer cells using exogenous interleukin-2, -7 or -12 . Cancer Immunol Immunother 1998, 47:221-226.

48. Helms MW, Prescher JA, Cao YA, Schaffert S, Contag CH: IL-12 enhances efficacy and shortens enrichment time in cytokine-induced killer cell immunotherapy. Cancer Immunol Immunother 2010, 59:1325-1334.

49. Okamura H, Tsutsi H, Komatsu T, Yutsudo M, Hakura A, Tanimoto T, Torigoe K, Okura T, Nukada Y, Hattori K, et al: Cloning of a new cytokine that induces IFN-gamma production by T cells. Nature 1995, 378:88-91.

50. Yang Q, Li G, Zhu Y, Liu L, Chen E, Turnquist H, Zhang X, Finn OJ, Chen X, LU B: IL-33 synergizes with TCR and IL-12 signaling to promote the effector function of CD8+ T cells. Eur J Immunol 2011, 41:3351-3360.

51. Gold JE, Ross SD, Krellenstein DJ, LaRosa F, Malamud SC, Osband ME: Adoptive transfer of ex vivo activated memory T-cells with or without cyclophosphamide for advanced metastatic melanoma: results in 36 patients. Eur J Cancer 1995, 31A:698-708.

52. Galluzzi L, Senovilla L, Zitvogel L, Kroemer G: The secret ally: immunostimulation by anticancer drugs. Nat Rev Drug Discov 2012, 11:215-233.

53. Butterfield LH, Vujanovic L: New approaches to the development of adenoviral dendritic cell vaccines in melanoma. Curr Opin Investig Drugs 2010, 11:1399-1408.

54. Michaud M, Martins I, Sukkurwala AQ, Adjemian S, Ma Y, Pellegatti P, Shen S, Kepp O, Scoazec M, Mignot G, et al: Autophagy-dependent anticancer immune responses induced by chemotherapeutic agents in mice. Science 2011, 334:1573-1577.

55. Stroncek DF, Berger C, Cheever MA, Childs RW, Dudley ME, Flynn P, Gattinoni L, Heath JR, Kalos M, Marincola FM, et al: New directions in cellular therapy of cancer: a summary of the summit on cellular therapy for cancer. J Transl Med 2012, 10:48.
56. Morgan RA, Dudley ME, Wunderlich JR, Hughes MS, Yang JC, Sherry RM, Royal RE, Topalian SL, Kammula US, Restifo NP, et al: Cancer regression in patients after transfer of genetically engineered lymphocytes. Science 2006, 314:126-129.

57. Johnson LA, Morgan RA, Dudley ME, Cassard L, Yang JC, Hughes MS, Kammula US, Royal RE, Sherry RM, Wunderlich JR, et al: Gene therapy with human and mouse T-cell receptors mediates cancer regression and targets normal tissues expressing cognate antigen. Blood 2009, 114:535-546.

58. Robbins PF, Morgan RA, Feldman SA, Yang JC, Sherry RM, Dudley ME, Wunderlich JR, Nahvi AV, Helman $L$, Mackall $C L$, et al: Tumor regression in patients with metastatic synovial cell sarcoma and melanoma using genetically engineered lymphocytes reactive with NY-ESO-1. J Clin Oncol 2011, 29:917-924.

59. Kochenderfer JN, Wilson WH, Janik JE, Dudley ME, Stetler-Stevenson M, Feldman SA, Maric I, Raffeld M, Nathan DA, Lanier BJ, et al: Eradication of Blineage cells and regression of lymphoma in a patient treated with autologous T cells genetically engineered to recognize CD19. Blood 2010, 116:4099-4102.

60. Kalos M, Levine BL, Porter DL, Katz S, Grupp SA, Bagg A, June CH: T cells with chimeric antigen receptors have potent antitumor effects and can establish memory in patients with advanced leukemia. Sci Trans/ Med 2011, 3:95ra73.

61. Brentjens RJ, Riviere I, Park JH, Davila ML, Wang X, Stefanski J, Taylor C, Yeh $\mathrm{R}$, Bartido S, Borquez-Ojeda O, et al: Safety and persistence of adoptively transferred autologous CD19-targeted T cells in patients with relapsed or chemotherapy refractory B-cell leukemias. Blood 2011, 118:4817-4828.

62. Kochenderfer JN, Dudley ME, Feldman SA, Wilson WH, Spaner DE, Maric I, Stetler-Stevenson M, Phan GQ, Hughes MS, Sherry RM, et al: B-cell depletion and remissions of malignancy along with cytokine-associated toxicity in a clinical trial of anti-CD19 chimeric-antigen-receptortransduced T cells. Blood 2011, 8:8.

63. Chan JK, Hamilton CA, Cheung MK, Karimi M, Baker J, Gall JM, Schulz S, Thorne SH, Teng NN, Contag CH, et al: Enhanced killing of primary ovarian cancer by retargeting autologous cytokine-induced killer cells with bispecific antibodies: a preclinical study. Clin Cancer Res 2006, 12:1859-1867.

64. Thakur A, Lum LG: Cancer therapy with bispecific antibodies: clinical experience. Curr Opin Mol Ther 2010, 12:340-349.

65. Choi BD, Cai M, Bigner DD, Mehta Al, Kuan CT, Sampson JH: Bispecific antibodies engage $T$ cells for antitumor immunotherapy. Expert Opin Biol Ther 2011, 11:843-853.

66. Dugast AS, Haudebourg T, Coulon F, Heslan M, Haspot F, Poirier N, Vuillefroy de Silly R, Usal C, Smit H, Martinet B, et al: Myeloid-derived suppressor cells accumulate in kidney allograft tolerance and specifically suppress effector T cell expansion. J Immunol 2008, 180:7898-7906.

67. Haymaker C, Wu R, Bernatchez C, Radvanyi L: PD-1 and BTLA and CD8(+) T-cell "exhaustion" in cancer: "Exercising" an alternative viewpoint. Oncoimmunology 2012, 1:735-738.

68. Todorovic M, Mesiano G, Gammaitoni L, Leuci V, Giraudo Diego L, Cammarata C, Jordaney N, Carnevale-Schianca F, Gallo S, Fagioli F, et al: Ex vivo allogeneic stimulation significantly improves expansion of cytokine-induced killer cells without increasing their alloreactivity across HLA barriers. J Immunother 2012, 35:579-586.

69. Thorne SH, Negrin RS, Contag CH: Synergistic antitumor effects of immune cell-viral biotherapy. Science 2006, 311:1780-1784.

70. Tang D, Kang R, Livesey KM, Zeh HJ 3rd, Lotze MT: High mobility group box 1 (HMGB1) activates an autophagic response to oxidative stress. Antioxid Redox Signal 2011, 15:2185-2195.

71. Amaravadi RK, Lippincott-Schwartz J, Yin XM, Weiss WA, Takebe N, Timmer W, DiPaola RS, Lotze MT, White E: Principles and current strategies for targeting autophagy for cancer treatment. Clin Cancer Res 2011, 17:654-666.

72. Tang D, Kang R, Livesey KM, Cheh CW, Farkas A, Loughran P, Hoppe G, Bianchi ME, Tracey KJ, Zeh HJ 3rd, Lotze MT: Endogenous HMGB1 regulates autophagy. J Cell Biol 2010, 190:881-892.

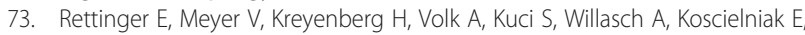
Fulda S, Wels WS, Boenig H, et al: Cytotoxic capacity of IL-15-stimulated cytokine-induced killer cells against human acute myeloid leukemia and rhabdomyosarcoma in humanized preclinical mouse models. Front Oncol 2012, 2:32. 
74. Rivera Z, Ferrone S, Wang X, Jube S, Yang H, Pass HI, Kanodia S, Gaudino G, Carbone M: CSPG4 as a target of antibody-based immunotherapy for malignant mesothelioma. Clin Cancer Res 2012, 18:5352-5363.

75. Sabbagh L, Kaech SM, Bourbonniere M, Woo M, Cohen LY, Haddad EK, Labrecque N, Ahmed R, Sekaly RP: The selective increase in caspase-3 expression in effector but not memory T cells allows susceptibility to apoptosis. J Immunol 2004, 173:5425-5433.

76. Joshi NS, Cui W, Chandele A, Lee HK, Urso DR, Hagman J, Gapin L, Kaech $\mathrm{SM}$ : Inflammation directs memory precursor and short-lived effector CD8 (+) T cell fates via the graded expression of T-bet transcription factor. Immunity 2007, 27:281-295.

77. Lugli E, Dominguez MH, Gattinoni L, Chattopadhyay PK, Bolton DL, Song K, Klatt NR, Brenchley JM, Vaccari M, Gostick E, et al: Superior T memory stem cell persistence supports long-lived T cell memory. J Clin Invest 2013, 123(2):594-599.

78. Lu B: The molecular mechanisms that control function and death of effector CD4+ T cells. Immunol Res 2006, 36:275-282.

79. Hirano F, Kaneko K, Tamura H, Dong H, Wang S, Ichikawa M, Rietz C, Flies DB, Lau JS, Zhu G, et al: Blockade of B7-H1 and PD-1 by monoclonal antibodies potentiates cancer therapeutic immunity. Cancer Res 2005, 65:1089-1096.

80. Kobori H, Hashiguchi M, Piao J, Kato M, Ritprajak P, Azuma M: Enhancement of effector CD8+ T-cell function by tumour-associated B7-H3 and modulation of its counter-receptor triggering receptor expressed on myeloid cell-like transcript 2 at tumour sites. Immunology 2010, 130:363-373.

doi:10.1186/1479-5876-11-83

Cite this article as: Jiang et al:: Cytokine-induced killer cells promote antitumor immunity. Journal of Translational Medicine 2013 11:83.

\section{Submit your next manuscript to BioMed Central and take full advantage of:}

- Convenient online submission

- Thorough peer review

- No space constraints or color figure charges

- Immediate publication on acceptance

- Inclusion in PubMed, CAS, Scopus and Google Scholar

- Research which is freely available for redistribution 